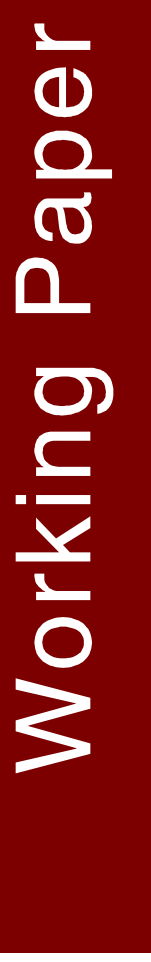

Case Study Approach to Region-wide Curriculum and Teaching Materials Development in Agroforestry Education in Southeast Asia

Jesus C. Fernandez and Per G. Rudebjer 



\section{Case Study Approach to Region-wide Curriculum and Teaching Materials Development in Agroforestry Education in Southeast Asia}

Jesus C. Fernandez ${ }^{1}$ and Per G. Rudebjer ${ }^{2}$

\footnotetext{
${ }^{1}$ Capacity Building Specialist, World Agroforestry Centre-Southeast Asia Regional Office, Bogor, Indonesia

${ }^{2}$ Scientist, Education and Capacity Development, Bioversity International, Rome, Italy
} 


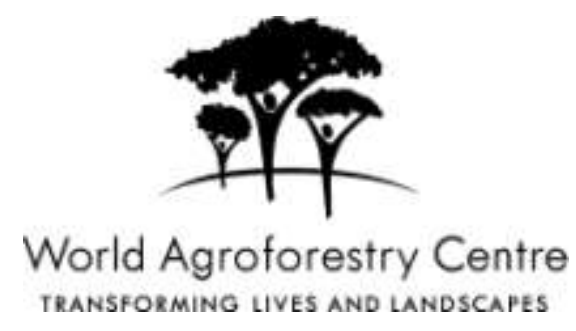

\section{Correct citation:}

Fernandez, J.C and Rudebjer, P.G. 2010. Case Study Approach to Region-wide Curriculum and Teaching Materials Development in Agroforestry Education in Southeast Asia. Working paper no. 101. Bogor, Indonesia: World Agroforestry Centre Southeast Asia Regional Office . 27p

Titles in the Working Paper Series aim to disseminate interim results on agroforestry research and practices and stimulate feedback from the scientific community. Other publication series from the World Agroforestry Centre include: Agroforestry Perspectives, Technical Manuals and Occasional Papers.

\section{Published by}

World Agroforestry Centre

ICRAF Southeast Asia Regional Office

PO Box 161, Bogor 16001, Indonesia

$$
\text { Tel: }+622518625415
$$

Fax: +62 2518625416

Email: icraf-indonesia@cgiar.org

http://www.worldagroforestrycentre.org/sea

(C) World Agroforestry Centre

Working Paper no 101

The views expressed in this publication are those of the author(s) and not necessarily those of the World Agroforestry Centre.

Articles appearing in this publication may be quoted or reproduced without charge, provided the source is acknowledged.

All images remain the sole property of their source and may not be used for any purpose without written permission of the source. 


\section{About the authors}

Dr. Jesus C. Fernandez is a Capacity Building Specialist at the World Agroforestry Centre (ICRAF)-Southeast Asia Regional Office in Indonesia and as Technical Adviser of the Southeast Asia Network for Agroforestry Education (SEANAFE). His tasks mainly involve curriculum and teaching materials development, organizing and implementing capacity building activities for university teachers and administrators, and agroforestry education advocacy.

Before joining ICRAF, Dr. Fernandez served as Manager of the Training Department of the Southeast Asian Center for Graduate Study and Research in Agriculture (SEARCA) in the Philippines. He also served as affiliate assistant professor at the College of Development Communication of the University of the Philippines Los Banos (UPLB).

Mr. Per G. Rudebjer is a Scientist at the Capacity Development Unit of Bioversity International based in Rome, Italy. He conducts studies and develops training materials and curriculum guides on agricultural biodiversity in collaboration with universities and network partners, and supports capacity development projects and activities of the organization. Prior to joining Bioversity, he worked for 11 years as Capacity Building Specialist at the World Agroforestry Centre in Kenya, Indonesia, and Thailand, advising university networks on agroforestry education in Africa and Southeast Asia. 


\title{
Preface
}

Agroforestry, as an evolving discipline and practice, continues to take on new roles and a renewed importance in addressing socioeconomic and environmental concerns worldwide. Among these concerns include improving poor farmers' gainful participation in markets for agroforestry tree products and optimizing land uses in various landscapes to provide secure livelihoods and environmental services to communities. In Southeast Asia, however, tertiary education courses that address socio-economic and environmental impacts of land use decisions and the functions of entire landscapes are usually lacking in most academic programs. The focus is more on plot- rather than landscape-level management and the supply rather than demand side of production. If dealt with at all, the landscape and demand aspects of agroforestry are only briefly discussed, at best, as a topic. As such, learning institutions are challenged to make their agroforestry education programs and courses more responsive to these and other rapidly changing global needs.

Curriculum and teaching materials development are inherent processes that learning institutions undertake to remain relevant in their program offerings. These processes are critical to help produce graduates that are equipped with basic and specialized knowledge and skills to render professional service. As it is incumbent to the Southeast Asian Network for Agroforestry Education (SEANAFE) to help its member-institutions enhance their agroforestry education offerings, the network embarked on two projects to develop region-wide curricular framework and teaching materials on Markets for Agroforestry Tree Products and Agroforestry Landscape Analysis from 2005-2009.

This working paper shares SEANAFE's innovative processes in bringing in real field conditions in developing curricular framework and teaching materials on the two subject matters using the case study approach. It was SEANAFE's attempt to bring agroforestry education closer to the practice and vice versa. I congratulate SEANAFE and the authors involved for putting together the network's project experiences in this working paper. I hope that this working paper would stimulate discussion on the usefulness of the case study approach and spark the desire among learning institutions to be more innovative in developing curricular and teaching materials toward a more relevant agroforestry education in the region.

\author{
UJJWAL PRADHAN, PhD
}

Regional Coordinator, ICRAF-SEA 


\section{Abstract}

Since 2005, the Southeast Asian Network for Agroforestry Education (SEANAFE) has developed region-wide curriculum frameworks and teaching materials on two important subject matters identified by its member universities, namely: 'marketing of agroforestry tree products (MAFTP)' and 'agroforestry landscape analysis (AFLA).' This paper shares the processes adopted and lessons learned by SEANAFE from both projects, which used a case study approach to bring practical experience into use for teaching and learning. Both projects were aimed to enhance the content of agroforestry education programs and courses, including the teaching capacity of lecturers and the quality of graduates, among SEANAFE's 87 member institutions in Indonesia, Laos PDR, the Philippines, Thailand, and Vietnam. For each of the two projects, multi-disciplinary teams of lecturers carried out the following activities within 18 months: (a) regional training to enhance the current state of knowledge on the two topics; (b) national case studies; (c) a workshop to formulate a curriculum framework and teaching material based on the results of the case studies; (d) translation of project outputs into local languages; (e) in-country training for 100 lecturers on using the curriculum framework and case studies material; and (e) supporting the mainstreaming of the project outputs into curricula. About 20 percent of SEANAFE member institutions have conducted curriculum reviews of existing agroforestry courses and/or programs to mainstream the outputs of the projects using the MAFTP and AFLA Teacher's Guides.

SEANAFE's project experiences have proven that building capacity to develop region-wide curriculum frameworks and teaching materials using the case study approach is feasible. The approach has also helped promote participatory curriculum development, maximize experiential and peer-based learning among teachers in the region, and enhance collaboration among SEANAFE member institutions.

\section{Keywords}

agroforestry education, capacity building, curriculum development, teaching materials development, Southeast Asia, agroforestry marketing, agroforestry landscape analysis 


\section{Acknowledgement}

The authors wish to thank the following:

- The Swedish International Development Cooperation Agency (Sida) for providing the funding for SEANAFE to carry out its projects on marketing of agroforestry tree products (MAFTP) and agroforestry landscape analysis (AFLA)

- The MAFTP and AFLA country teams, including their respondents and key informants, for generating the project experiences and outputs

- The World Agroforestry Centre and partners such as Regional Community Forestry Training Center (RECOFTC), Netherlands Development Organization (SNV), German Development Foundation (GTZ), and the International Center for Tropical Agriculture (CIAT) for providing technical and logistical assistance during the MAFTP and AFLA project implementation

- Prof. August Temu and Dr. Yaye Aissetou for reviewing this working paper

- Andrew Warner and Lily Tallafer for the initial and final editing of this working paper, respectively 


\section{Contents}

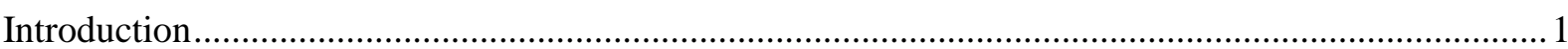

Why the Marketing and Landscape Projects? ................................................................................. 2

Overall Marketing and Landscape Project Framework .......................................................................

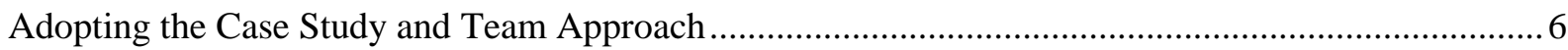

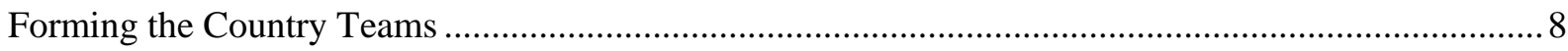

Setting the Direction for and with the Country Teams .......................................................................

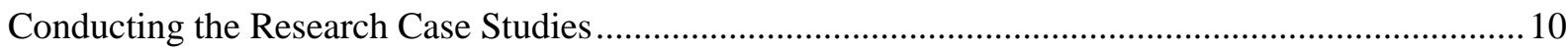

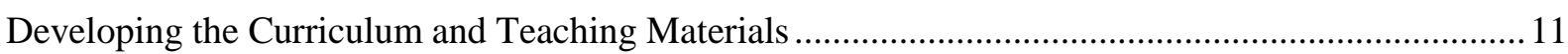

Refining and Translating the Teaching Case Studies and Conducting In-country Trainings ................ 16

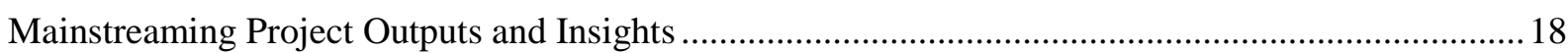

Conclusions, Lessons Learned and Recommendations ..................................................................... 19

Some Challenges in Institutionalizing SEANAFE Project Experiences and Outputs .........................2 21

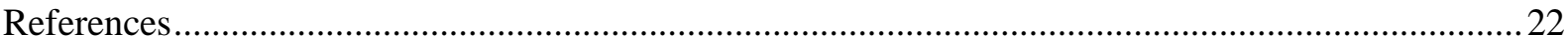

\section{List of Figures}

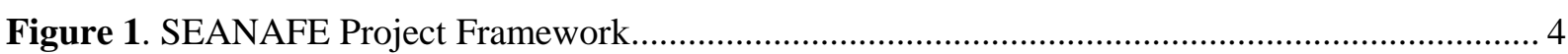

Figure 2 MAFTP and AFLA project processes in developing curriculum framework......................... 12

\section{List of Tables}

Table 1. Specific objectives of the SEANAFE Marketing and Landscape Projects. .............................. 5

Table 2. Topics of MAFTP and AFLA case studies of the country teams........................................... 7

Table 3. MAFTP curricular themes and their brief descriptions................................13

Table 4. AFLA curricular themes and their brief descriptions.....................................

Table 5. Breakdown of Marketing and Landscape Project training participants per country ............ 17 


\section{Acronyms}

AFLA Agroforestry Landscape Analysis

AFTP Agroforestry tree products

CIAT International Centre for Tropical Agriculture

EFPE Enhancing Forestry and Environmental Policy Education

GTZ German Development Foundation

ICRAF World Agroforestry Centre

MAFTP Markets for Agroforestry Tree Products

RECOFTC Regional Community Forestry Training Center

SEANAFE Southeast Asian Network for Agroforestry Education

Sida Swedish International Development Cooperation Agency

SNV The Netherlands Development Organization 


\section{Introduction}

Curriculum and teaching materials development have been among the major functions of the Southeast Asian Network for Agroforestry Education (SEANAFE) since its establishment in 1999. SEANAFE is a network of learning institutions, mostly universities and colleges, offering Bachelor and Master of Science degrees in agriculture and forestry in Indonesia, Laos PDR, Malaysia, the Philippines, Thailand, and Vietnam. Its membership has expanded from 87 in 2006 to 94 in 2009 with the establishment of the Malaysian country network. SEANAFE's mission is to 'help improve agroforestry education, training, research, and extension, and contribute to socioeconomic development, empowerment of farming communities, and sustainable natural resources and environmental management in the Southeast Asian region.'

The second phase of SEANAFE's operation (2005-2009) was conceived to enable educators from its member institutions to share knowledge and develop learning tools that address the interface between environmental conservation and poverty alleviation. It recognizes the fact that "the complex interface between these two areas must be handled in a holistic and integrated way if it is to help millions of small-scale farmers benefit from commercial markets and, at the same time, help them to manage local landscapes" [1]. Thus, the SEANAFE Phase 2 Project was guided by the overarching goal of educating Southeast Asia's next generation of educators, scientists, and decision makers, particularly those currently enrolled in forestry and agriculture universities, on the importance of these issues so that they can enact effective policies and programs. SEANAFE, through funding support from the Swedish International Development Cooperation Agency (Sida), organized its Phase 2 set of activities around the implementation of a series of regional projects identified by the SEANAFE Board. These themed projects included a) Markets for Agroforestry Tree Products (MAFTP); b) Agroforestry Landscape Analyses (AFLA); and c) Enhancing Forestry and Environmental Policy Education (EFPE). This paper will elaborate more on the MAFTP and AFLA Project experiences. The MAFTP and AFLA Projects will be refered in this paper as Marketing Project and Landscape Project, respectively. 


\section{Why the Marketing and Landscape Projects?}

ICRAF's research activities in agroforestry marketing and landscape analysis and the need to integrate these concepts in university curricula provided the impetus for SEANAFE to conceptualize and implement the MAFTP and AFLA projects [2,3].

Most countries in Southeast Asia have experienced structural shift from subsistence to a market economy due to the rapid socio-economic and environmental changes that have taken place in the region in the last decade. These changes included unprecedented national economic growth; greater investment in infrastructure, particularly roads and communication facilities; implementation of new international trade agreements; changing land uses; depletion of the region's natural resources; and population growth. Such changes, amongst others, have influenced traditional trading patterns and led to the emergence of new markets, including markets for agroforestry tree products (AFTP). AFTP include both wood and non-wood products, as well as environmental services, which makes agroforestry markets huge, diverse, and hard to characterize. The overlap between markets of forestry and agriculture and the lack of sufficient and reliable market information, such as published market prices, aggravate the situation for marketing AFTP.

Many of the region's farmers are unable to tap the full potential of their production capacity and have not achieved gainful participation in markets due to several factors including: limited working capital; lack of access to information on markets; low domestic demand; inability to produce quality products or provide a steady supply required by the markets; poor infrastructure; lack of knowledge and understanding of standards; and lack of skills and/or capital needed to generate additional income through post-harvest processing and value-adding. Other social and political constraints also complicate the scenario, such as taxes and formal and informal fees that increase risk and add to transaction costs. Thus, efforts to improve poor farmers' gainful participation in markets for AFTP must consider how the necessary conditions for market access can be created ranging from traditional products traded only locally, to commodities traded globally.

Similarly, the region's upland landscapes are being affected in response to the abovementioned changes. The ability of landscapes to provide secure livelihoods for their inhabitants and environmental services for society depends on their economic, social and biophysical 'connectivity'. Likewise, the way landscapes are used and managed contributes both to the maintenance of existing environmental services, and to the rebuilding of services that may have been lost through unsustainable practices. On the other hand, impacts of natural disasters on lives and landscapes can be reduced by good land management. For example, many agroforestry systems can protect the soils better than mono-cropping systems. Integrated solutions are required that can optimize land use across the different zones of the landscape. This highlights the importance of understanding the function of an entire landscape, or nested levels of landscapes.

However, courses that address environmental impacts of land use decisions and the functions of entire landscapes are usually lacking in most university programs. The focus is more on plot-level management, rather than the larger landscape, which ignores the off-site effects of land use decisions 
on water quality, nutrient losses, agrochemical contamination, and biodiversity. Most university courses fail to consider that integration of different land use disciplines may provide an overall healthier landscape. Likewise, most agroforestry education programs and courses in Southeast Asia place a low emphasis on the demand aspects of agroforestry, especially the links between producers and consumers, markets, post-harvest processing and small-scale livelihood systems. In most cases, agroforestry education in the region is still biased towards production or the supply side of production. If dealt with at all, demand aspects are only briefly discussed, at best, as a topic.

The issues mentioned here strengthened the rationale for selecting MAFTP and AFLA as SEANAFE's project themes. By systematically studying these issues toward developing curriculum frameworks and teaching materials on these subject matters, SEANAFE believed that the competence (knowledge, skills, and attitudes) that students should acquire related to MAFTP and AFLA could be enhanced. Together, these projects could provide a better perspective to the students about small-scale farmers and their potential as a business, as well providing insights into how agroforestry markets impact on livelihoods and landscapes. 


\section{Overall Framework of the Marketing and Landscape Projects}

Both SEANAFE's Marketing and Landscape projects had two general objectives, namely: a) to improve agroforestry education in universities and colleges in Southeast Asia (SEA) by developing region-wide curriculum frameworks and teaching materials in English and national languages, and b) to enhance the teaching capacity of at least 100 lecturers from SEANAFE member institutions on the two subjects. These objectives were geared toward helping realize SEANAFE's mission of improving the livelihood of the poor farming families in the region through quality agroforestry education. As shown in Figure 1, the projects envisioned three educational impacts. In the short term, the projects expected to enrich agroforestry teaching materials in SEANAFE institutions through the adoption of the country case studies. In the midterm, the projects hoped to stir more curriculum development and reviews among universities and colleges within and outside the SEA region to incorporate marketing and landscape themes in existing agroforestry curricula. In the long term, SEANAFE looks forward to offering marketing and landscape curricula as separate courses within agriculture and/or forestry programs in its member institutions.

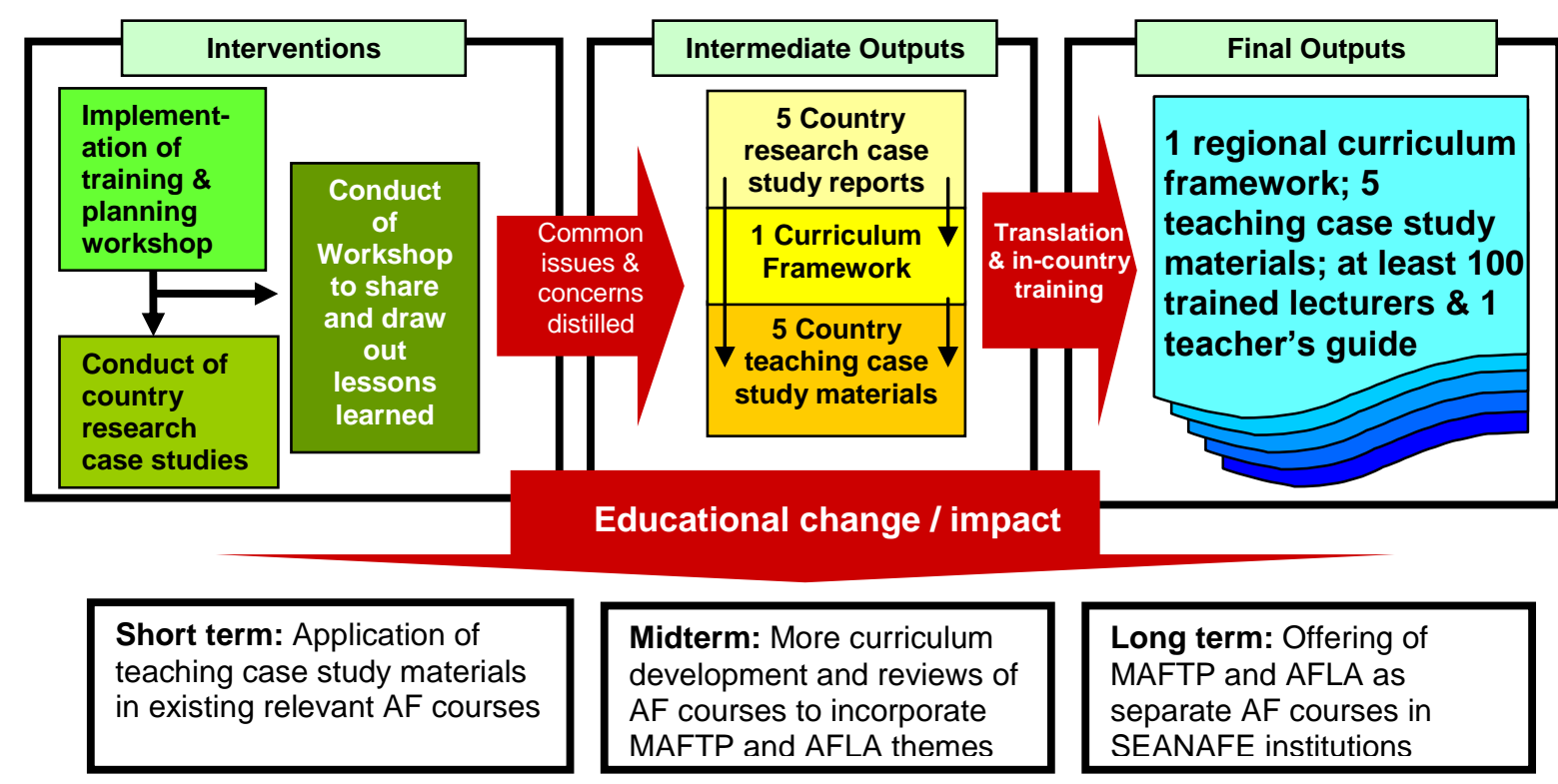

Figure 1. SEANAFE Project Framework.

SEANAFE formed country teams to help accomplish the project objectives within 18 months. Each team consisted of at least four members having complementary competencies from SEANAFE member institutions. Table 1 lists the specific objectives of the two projects. 
Table 1. Specific objectives of the SEANAFE Marketing and Landscape Projects.

1. Review and understand principles for smallholders' gainful participation in markets for agroforestry tree products; and

2. Identify and characterize key types of markets for agroforestry tree products in Southeast Asia.
1. Review and understand the principles of how mosaic agroforestry landscapes function; and

2. Identify and characterize key drivers behind landscape changes, and be able to use participatory tools and methods for studying landscape dynamics.

Each project was expected to produce the following outputs:

- A regional synthesis/review of current knowledge, skills, methods, and tools on the given subject matter;

- Five national research case studies;

- A regional curriculum framework and five teaching case studies in English and the national languages of SEANAFE member countries;

- Capacity building for at least 100 teachers in Southeast Asia; and

- Institutionalization of the project outputs in existing agroforestry and related courses in SEANAFE member institutions. 


\section{Adopting the Case Study and Team Approach}

SEANAFE thought that developing a curriculum framework using the case study approach could be more problem-oriented and broad field-centered [4]. Being broad field-centered means that several separate concepts related to the subject matter are considered in an interdisciplinary framework. This puts the subject matter in a wider perspective and generates fresher insights and experiences that can then be used to formulate a curriculum. In the process, it provides the basis for activities in which learners can compare and contrast related areas, developing interdisciplinary understanding and appreciation of the subject matter based on real-world conditions. On the other hand, being problemoriented means being interdisciplinary and participatory, highlighting real situations, and engaging learners to think more critically about the subject matter.

As defined by Yin [5], a case study is an "empirical inquiry that investigates a contemporary phenomenon within its real-life context; when the boundaries between phenomenon and context are not clearly evident; and in which multiple sources of evidence are used." Following this definition, SEANAFE relied on the strength of a case study with its ability to deal with a variety of evidences collected from various sources which could be triangulated to produce the desired project outputs. There was support from Stake's [6] argument, too, that adopting the case study approach for the projects is "not so much of a methodological choice but a choice of what is to be studied."

Case studies can be classified into two types, i.e., a research case study and a teaching case study. A research case study can be said to contain a full description of the case being studied, including analysis, conclusions, and recommendations. Its main purpose is for the reader to fully understand the case being studied and generate experiences and lessons. On the other hand, a teaching case study deliberately does not include much analysis, or many conclusions and recommendations with regard to the case being studied. Rather, the purpose is to challenge and stimulate the learner's behavioral skills in analysis and critical thinking on what actions to take if they were in the same situation as the one described in the case [7]. Both types of case studies were produced for the Marketing and Landscape projects. In this paper, research case studies refer to the full versions of the case studies produced by the country teams. They served as inputs to generate the curriculum framework on MAFTP and AFLA and for subsequently developing the teaching case study materials. Thus, the teaching case studies refer to the repackaged versions of the research case studies. 
Table 2. Topics of MAFTP and AFLA case studies of the country teams.

\begin{tabular}{|c|c|}
\hline MAFTP & AFLA \\
\hline $\begin{array}{l}\text { 1. Market Chain Analysis of Cashew Nuts in } \\
\text { Wonogiri District, Central Java Province, } \\
\text { Indonesia }\end{array}$ & $\begin{array}{l}\text { 1. Agroforestry Landscape Analysis In } \\
\text { Mendalam River Basin, The Upper Stream } \\
\text { Of Kapuas Watershed, West Kalimantan } \\
\text { Province, Indonesia }\end{array}$ \\
\hline $\begin{array}{l}\text { 3. Market Development for Coconut-Based } \\
\text { Agroforestry Farms in Quezon Province, } \\
\text { Philippines }\end{array}$ & $\begin{array}{l}\text { 2. Landscape Changes in Nam Thone } \\
\text { Watershed, Pakading District, Bolikhamxay } \\
\text { Province, Lao PDR }\end{array}$ \\
\hline $\begin{array}{l}\text { 4. Marketing of Para Rubber Products of } \\
\text { Small-Scale Farmers in Northern Thailand }\end{array}$ & $\begin{array}{l}\text { 3. Landscape Agroforestry Dynamics in Two } \\
\text { Sub-Watersheds Within the Makiling Forest } \\
\text { Reserve In Los Baños, Laguna, Philippines }\end{array}$ \\
\hline $\begin{array}{l}\text { 5. Cashew Nut Supply Chains in Dak Nong } \\
\text { and Binh Phuoc Provinces, Vietnam }\end{array}$ & $\begin{array}{l}\text { 4. Landscape Agroforestry Mapping and } \\
\text { Planning for Sufficiency Economy in } \\
\text { Huairaeng-Khlong Peed Watershed in } \\
\text { Eastern Thailand }\end{array}$ \\
\hline & $\begin{array}{l}\text { 5. Study on Upland Maize-Based Landscape } \\
\text { Agroforestry in Son La Province, Northern } \\
\text { Vietnam }\end{array}$ \\
\hline
\end{tabular}

As a capacity building activity of SEANAFE, the projects adopted the team and participatory approaches for the following reasons:

- To maximize experiential and peer-based learning among country team members, while undertaking the various project activities toward producing the expected project outputs;

- To involve key stakeholders during the country teams's research and project workshops, which also would be beneficial for subsequent participatory curriculum development;

- To maximize consensus building among country teams to heighten ownership of the project outputs toward enhanced advocacy of MAFTP and AFLA concepts and tools; and

- To enhance interaction among SEANAFE member institutions. 


\section{Forming the Country Teams}

The SEANAFE Board developed criteria for composing the project country teams which included: (1) gender representation, (2) expertise in key areas related to the subject matter, and (3) participation of different institutions and younger lecturers. On the qualifications of the team members, they should at least: (1) be engaged in teaching and/or research in SEANAFE member institutions; (2) have working knowledge of oral and written English language; and (3) be available throughout the project duration. SEANAFE national network chairs endorsed their respective team nominees, together with their curriculum vitae, to the SEANAFE Board for final selection. 


\section{Setting the Direction for and with the Country Teams}

The first regional training-cum-planning workshops for both projects (Please see Attachments 1 and 2 ) set the directions for the country teams to carry out project activities. The workshops were geared toward achieving the following objectives:

1. Level off working knowledge and experiences and update the country team members on the concepts, principles and issues of MAFTP and AFLA;

2. Enable the country teams to collectively identify the competencies that students should acquire on MAFTP and AFLA and identify the educational gaps toward drafting a curriculum framework for the relevant subject matter;

3. Provide direction and guidance to the country teams in finalizing and then drafting concept proposals for the research topics for their respective country research; and

4. Formulate effective working arrangements and schedules for both SEANAFE and the country teams in conducting project activities.

SEANAFE implemented the training-cum-planning workshops in collaboration with several agencies that had the same interest and expertise in the two subjects. They included: the Regional Community Forestry Training Center (RECOFTC), Netherlands Development Organization (SNV), German Development Foundation (GTZ), World Agroforestry Centre (ICRAF), and the International Center for Tropical Agriculture (CIAT). These agencies provided either financial support or expertise during workshop sessions.

Behind all the planned activities of the training-cum-planning workshop was the underlying purpose of building teamwork among the members. Thus, during small group workshops and discussion sessions, all opportunities were maximized to enable members to learn about each other's personaland team-working styles, particularly in decision-making. 


\section{Conducting the Research Case Studies}

Each country team was requested to submit a case study proposal a month after the training-cumplanning workshop. SEANAFE and its project partner institutions extended technical assistance to all country teams to finalize their case study proposals. Letters of agreements were then signed between SEANAFE and the respective institutions of the country team leaders to carry out the case studies for six months.

The teams used various methods, ranging from secondary data sourcing to focused group interviews, to generate data for their case study research. Information was gathered from many types of respondents because the teams differed in the level of their study sites, i.e., either village, district, municipal or provincial levels. This situation surfaced more relevant issues and concerns about MAFTP and AFLA, which served as critical inputs in the development of the curriculum frameworks.

To keep the case study activities on track, SEANAFE sustained technical assistance to the teams, albeit through the email system. The teams were also required to submit progress reports which were referred to ICRAF experts for critiquing and advice. In addition, at least one coordinators' meeting for each project was conducted to discuss and address both the logistical and technical concerns of the teams

After data gathering, the country team members developed their research case study report electronically. Team meetings to discuss outputs personally were constrained by the available project funds. 


\section{Developing the Curriculum and Teaching Materials}

After completion of the research case studies, SEANAFE conducted a second regional workshop for each project to (1) present and compare the research case study results and experiences of the teams, (2) finalize curriculum frameworks and (3) convert the research case study reports into teaching case study materials.

In developing the curriculum framework, SEANAFE adopted somewhat different approaches for the two projects. Having identified the competency requirements for students related to the curriculum framework of the two subjects during the first regional country team workshops, the projects conducted different sets of related activities during subsequent project phases (Fig 2).

The Marketing Project adopted an inductive way of developing its curriculum framework. The key themes that made up the curriculum framework were identified late in the process, derived from the common observations, issues, and concerns that surfaced from the analysis of the country research case study results.

The Landscape Project followed a deductive process, such that key themes of the curriculum framework were identified first. The themes were then used to guide the conduct of the country research case studies to generate observations, issues, and concerns as additional inputs to formulating a curriculum framework. This change in the approach was aimed at determining whether such a process would affect the quality of research outputs, the cross-country analysis, generalization of findings toward the development of the curriculum frameworks, and teaching case studies material.

Tables 3 and 4 list the curricular themes and their corresponding brief descriptions for each of the subject matters as formulated by the country teams. 


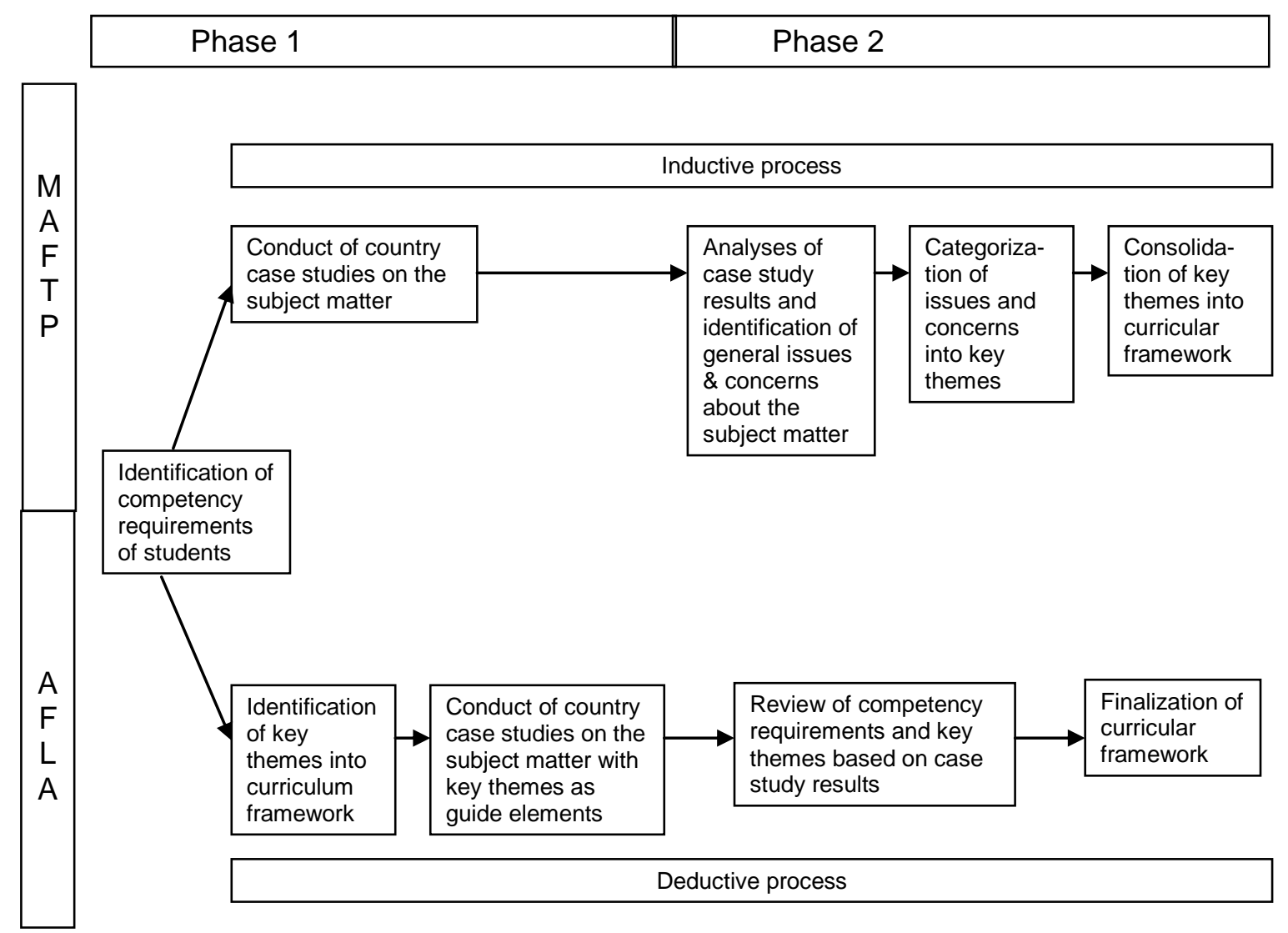

Figure 2 Marketing and Landscape Project processes in developing curriculum framework. 
Table 3 MAFTP curricular themes and their brief descriptions.

\begin{tabular}{|l|l|}
\hline $\begin{array}{l}\text { Theme 1: Agroforestry Situationer in Southeast } \\
\text { Asia }\end{array}$ & $\begin{array}{l}\text { Sets the tone of the course and provides an overview } \\
\text { of the state of agroforestry in the region including its } \\
\text { potentials and challenges in the light of emerging } \\
\text { global concerns }\end{array}$ \\
\hline $\begin{array}{l}\text { Theme 2: Sustainable Agroforestry Production, } \\
\text { Trade, and Consumption in Southeast Asia }\end{array}$ & $\begin{array}{l}\text { Discusses agroforestry as a development sector } \\
\text { including its markets and the roles and responsibilities } \\
\text { of its various actors in ensuring its development and } \\
\text { sustainability in the context of current and potential } \\
\text { challenges, including gender issues; also provides an } \\
\text { introduction to basic marketing concepts in relation to } \\
\text { agroforestry development and also outlines some basic } \\
\text { steps in marketing agroforestry products through } \\
\text { market research, marketing plan preparation, } \\
\text { implementation and evaluation. }\end{array}$ \\
\hline Theme 3: Value Chain Analysis and & $\begin{array}{l}\text { Explains value chain concepts and processes as well as } \\
\text { the various chain participants adding value to the } \\
\text { product as it passes through the chains; emphasizes on } \\
\text { the importance of agroenterprise development and } \\
\text { promotion, constant production innovation and quality } \\
\text { assurance towards sustaining agroforestry chains }\end{array}$ \\
\hline Throenterprise Development & $\begin{array}{l}\text { Provides an overview of the varying regional and } \\
\text { country requisites that enable agroforestry } \\
\text { development and product marketing; analysis of what } \\
\text { works and did not work to enhance policy input, } \\
\text { formulation, and implementation in support of } \\
\text { sustainable agroforestry }\end{array}$ \\
\hline Marketing &
\end{tabular}


Table 4. AFLA curricular themes and their brief descriptions.

\begin{tabular}{|c|c|}
\hline Themes & Brief Descriptions \\
\hline Theme 1: Introduction to Landscape Agroforestry & $\begin{array}{l}\text { Deals with basic concepts and principles of landscape } \\
\text { agroforestry and mosaics of forest, agriculture, and } \\
\text { agroforestry; includes relationships with concepts } \\
\text { developed in related fields of study such as farming } \\
\text { systems, community forestry, agroforestry systems, } \\
\text { agroecosystems, watershed management, landscape } \\
\text { architecture, landscape ecology,etc.; emphasizes on } \\
\text { the roles of historical change, spatial scale and system } \\
\text { boundaries }\end{array}$ \\
\hline Theme 2: Characterizing Agroforestry Landscapes & $\begin{array}{l}\text { Touches on approaches for identifying, assessing, and } \\
\text { understanding important properties, characteristics, } \\
\text { patterns, and dynamics of agroforestry landscapes; } \\
\text { introduces the three complementary approaches to } \\
\text { 'knowing' and 'understanding' that are embedded in } \\
\text { local knowledge, public/policy discourse, and science. }\end{array}$ \\
\hline $\begin{array}{l}\text { Theme 3: Drivers of Change in Agroforestry } \\
\text { Landscapes }\end{array}$ & $\begin{array}{l}\text { Focuses on identifying and understanding the forces } \\
\text { and processes that drive change(s) in configuration } \\
\text { and/or dynamics in agroforestry landscapes which } \\
\text { could be based in biophysical, environmental, social, } \\
\text { economic, cultural, institutional or political realities, at } \\
\text { at local to global levels over a given period of time. }\end{array}$ \\
\hline $\begin{array}{l}\text { Theme 4: Tools, Methods, and Approaches in } \\
\text { Agroforestry Landscape Analysis }\end{array}$ & $\begin{array}{l}\text { Provides an overview of available approaches, } \\
\text { methods, and tools potentially useful in defining and } \\
\text { characterizing agroforestry landscapes in an } \\
\text { interdisciplinary way; includes approaches to identify } \\
\text { and understand forces driving change in configuration } \\
\text { or dynamics }\end{array}$ \\
\hline $\begin{array}{l}\text { Theme 5: Planning and Managing Agroforestry } \\
\text { Landscapes }\end{array}$ & $\begin{array}{l}\text { Centers on the potential roles of landscape assessment, } \\
\text { planning, management, and monitoring in negotiations } \\
\text { among stakeholders of rules and incentives that } \\
\text { influence drivers of change }\end{array}$ \\
\hline
\end{tabular}

SEANAFE also applied a different approach in developing the teaching case study materials for each project. For the Marketing project, the country teams were requested to identify at least three key MAFTP themes that were prominently discussed in their research case studies. The teams were further requested to develop a teaching framework on these key themes containing: (1) issues and learning points found in their respective research case studies, (2) the information to be highlighted in the teaching case studies that eventually would be developed, (3) guide questions for discussing the issues and learning points, and (4) suggested methods to teach the three key themes chosen. SEANAFE and the country teams agreed to hire an external editor-cum-case study writer to convert the country research case studies into teaching case studies using the teaching frameworks produced. The plan was to write short, easy-to-read teaching case study materials that could encourage greater learning by the students on the various MAFTP curricular themes. Thus, it was important that the external editor cum case study writer has considerable background on the individual actors in the chain studied, their issues and concerns, and the major lessons shared to give the teaching case study material a more realistic feel. 
Learning from the experiences of the Marketing project, SEANAFE allotted more time during the Landcape project's second regional workshop to enable the team members to draft their respective teaching case study materials. To accomplish this, SEANAFE tapped the services of two case study writers from RECOFTC to guide the team members in distilling the key issues and messages of their research case studies and consolidating them into teaching case studies. Following the peer-based learning approach, the country teams were requested to critique and improve each other's outputs. One month after the workshop, the country teams submitted the improved versions of the teaching case study materials to the case study writers for final editing. After the revisions, SEANAFE finally packaged the teaching case studies for translation into the local languages of the country teams during AFLA's Phase 2 implementation. 


\section{Refining and Translating the Teaching Case Studies and Conducting In-country Trainings}

Phase 2 of both projects consisted primarily of translation of the teaching case studies into the local languages of the participating countries and the conduct of in-country training on using the project outputs. The country teams received another set of contracts from SEANAFE for this phase.

To help achieve the Phase 2 activities, SEANAFE conducted a team coordinators' meeting for each project. Such meeting was aimed to: (1) revisit and finalize the scopes of the key themes of the curriculum frameworks; (2) finalize the teaching case studies material for translation into the local languages of the SEANAFE member countries; (3) finalize the country team proposals and terms of reference for project Phase 2 implementation; (4) agree on the major processes and basic activities that the country team would undertake for Phase 2 including the design of the in-country training; (5) familiarize the country teams with some practical tips on organizing and implementing an in-country training course; and (6) agree on the implementation of the timetable of activity for the Project.

Once again, SEANAFE adopted a peer-based approach during the coordinators' meeting in finalizing the teaching case studies. In reviewing the materials, the coordinators were asked to: (1) identify areas needing more clarification (i.e., were there still info gaps, data consistencies? What assumptions need to be formulated? Is it comprehensible to the students? What parts need to be simplified?); (2) assess if there is a match between and among the material content, key themes being discussed, and guide questions that need to be answered by the students; (3) determine if the material can provide answers to the guide questions for the students; and (4) assess if the suggested activities are relevant and implementable and provide suggestions, if otherwise. The final versions of the case study materials were translated in Indonesian, Lao, Thai, and Vietnamese languages and edited either by the country team members themselves or by an expert contracted by them. Translation was not needed in the case of the Philippines as English is the medium of instruction in universities and colleges.

Though country coordinators agreed on a common in-country training design, the country teams were nevertheless given flexibility to adopt various approaches in implementing their respective training activities. SEANAFE recognized that the country teams had different working knowledge in implementing a training course. In discussing the key themes of the curriculum framework, either the country teams served as the resource persons or they invited experts to lecture on the themes. In sampling the case study materials, on the other hand, the teams either adopted a plenary approach and/or small group discussions. For the Marketing project, 109 lecturers, researchers, and extension staff from 72 learning organizations, mostly SEANAFE members, benefitted from the in-country training. The Landscape Project, on the other hand, trained 105 lecturers and researchers from 71 SEANAFE member institutions. Table 5 contains a breakdown of the participants and institutions per country. 
Table 5. Breakdown of Marketing and Landscape Project training participants per country.

\begin{tabular}{|lcccc|}
\hline \multicolumn{1}{|c}{ Country } & No. of Participants & No. of Institutions & No. of Participants & $\begin{array}{c}\text { No. of } \\
\text { Institutions }\end{array}$ \\
\hline Indonesia & 21 & 16 & 17 & 17 \\
\hline Laos PDR & 20 & 10 & 17 & 9 \\
\hline The Philippines & 28 & 28 & 29 & 26 \\
\hline Thailand & 21 & 10 & 24 & 10 \\
\hline Vietnam & 19 & 8 & 18 & 9 \\
\hline Total & $\mathbf{1 0 9}$ & $\mathbf{7 2}$ & $\mathbf{1 0 5}$ & $\mathbf{7 1}$ \\
\hline
\end{tabular}




\section{Mainstreaming Project Outputs and Insights}

SEANAFE's post Marketing and Landscape project activities focused supporting the mainstreaming of the project outputs and experiences in member universities and colleges. Thus, SEANAFE allocated small grants to its member institutions to undertake curriculum reviews and similar activities (e.g., stakeholders' dialogue/consultation meetings, seminars). Specifically, the small grants were aimed at accomplishing either of the following project mainstreaming objectives/educational impacts: (1) institutionalizing the use of the SEANAFE MAFTP and AFLA research and teaching case study materials in any existing courses where relevant; (2) incorporating the key themes of MAFTP/AFLA curricular frameworks in existing agroforestry and related courses; and (3) offering an entire MAFTP/AFLA course within an existing BS Agriculture/Forestry/ Agroforestry and related programs with the case studies as major teaching materials. This component was also SEANAFE's way of validating the relevance of the project outputs and experiences. It was also building institutional capacities of SEANAFE member institutions as most mainstreaming activities involved orientations of faculty members and administrators on the subject matter.

For the Marketing Project, 17 out of the 72 institutions that participated in the in-country training took advantage of the SEANAFE mainstreaming grant i.e., 6 from Thailand, 5 from the Philippines, 3 from Indonesia, 2 from Laos PDR, and 1 from Vietnam. In most cases, the grantees focused on incorporating themes of MAFTP into existing agroforestry and related courses offered in their respective institutions via 3-to-8 contact hours of coverage within a semester. Value Chain Analysis and Agroenterprise Development appeared to be the most common themes integrated into existing agroforestry and related courses by a majority of the institutions. One institution in the Philippines proposed offering the MAFTP curriculum as an elective course under its B.Sc. Agroforestry program. Though the MAFTP Teacher's Guide contains the proposed teaching design and suggested reference materials for teaching the various themes, the challenge is for the teachers to look for related teaching material in a local language for ease of understanding by the students. It is for this reason that one institution in Indonesia decided to develop a full set of lecture notes on the MAFTP key themes in the Indonesian language. Copies of these lecture notes have been published already and distributed to SEANAFE member institutions in Indonesia for teaching purposes.

The Landscape Project outputs were mainstreamed by 7 SEANAFE institutions, i.e., 2 institutions each in Indonesia, Lao PDR and the Philippines, and 1 from Vietnam. The two institutions from Lao PDR focused on integrating Themes 2 (Characterizing Agroforestry Landscapes) and 3 (Drivers of Change in Agroforestry Landscapes) into their existing agroforestry courses. A course syllabus and a complete set of lecture materials on AFLA in Bahasa Indonesia and English were produced by the institutions in Indonesia and Philippines, respectively. These materials have been distributed to all SEANAFE member institutions in these countries. Interestingly, Vietnam conducted an in-country training on AFLA for 25 extension workers in Central Highlands of the country. 


\section{Conclusions, Lessons Learned and Recommendations}

Building capacity to develop region-wide curriculum frameworks and teaching materials using the case study approach is feasible based on SEANAFE's Marketing and Landscape project experiences. In addition, the approach has (a) proven to promote participatory curriculum development through the involvement of key information sources during the conduct of the research; (b) stimulated experiential and peer-based learning among teachers in the region; and (c) enhanced collaboration and knowledge sharing among SEANAFE member institutions.

However, SEANAFE believes that refinements are necessary to make the process more effective and efficient considering the long duration and the relatively high cost requirement of the projects. Below are the general lessons learned and recommendations of SEANAFE to improve the process:

1. The kind of expertise and quality of commitment and working dynamics among the team members played a critical role in generating the expected project outputs. While the commitment and teamwork among members could not be ascertained at the onset of the selection process, it is essential that a more detailed selection criteria and team work mechanisms should be developed and carefully implemented. Team building activities could have been incorporated throughout the project duration, especially during the first country team training-cum-planning workshop. This would allow the teams to develop their own sets of work norms toward ensuring effective interpersonal communication and smooth working relationships.

2. Mobilizing team members coming from different universities in different locations was difficult due to differences in their work commitments in their respective institutions. As observed, the team coordinator took on most of the responsibilities. This may have been addressed better if the country network coordinators had played a more prominent role in orientating the respective supervisors of other team members. Since the contract for project implementation was between ICRAF and the institution where the project leader came from, a separate partnership statement should have been issued to other participating institutions. In the process, this would help their supervisors understand the demand for the members' involvement in the implementing the project. Further, copies of the timetable of project deliverables should have been distributed to the members' supervisors for monitoring purposes.

3. Since most, if not all, of the team members were lecturers/researchers, they were more familiar with technical research report writing than writing of teaching case studies. More lecture sessions and exercises on case study writing should have been an integral part of the first regional training-cum-planning workshop, while a review of the same writing principles should have been included in the second workshop design for both projects. This remedial 
action was only made during the coordinators' meeting for the Marketing project and during the second regional workshop for the Landscape project.

4. More technical input was given to the country teams on better appreciating and understanding the MAFTP and AFLA concepts and principles than on the process of producing the target outputs (e.g. the curriculum framework and case study materials) during the project training and workshops. This may have been due to the fact that SEANAFE capitalized on the experiential and peer-based learning approach in developing the curriculum and teaching materials and with the assumption that the team members were already familiar with the process. On the contrary, equal attention must be given in clarifying concepts and principles of the subject matters and the development of the expected outputs.

5. SEANAFE had provided adequate guidelines, tips and reminders on carrying out project activities through email and phone calls. However, a much more cohesive and comprehensive set of outputs and outcomes could have been produced by the country teams, especially in the conduct of their research and in-country training, if there had been more personal mentoring and closer monitoring from the SEANAFE technical adviser and/or the experts who were provided from partner institutions. Though this may require additional cost, practical arrangements could be developed.

6. Curriculum frameworks can be done through inductive or deductive process based on the experiences of the 2 projects. However, the latter appears to be a more practical option for guiding the country teams in conducting their respective research case study projects and for more effective cross-country identification and validation of common issues on the subject matter resulting from the research results.

7. Proper selection of participants in the in-country training courses on the use of the curriculum frameworks and teaching materials is important. This is to achieve the objective of mainstreaming the subject matter in existing agroforestry courses in SEANAFE member institutions and gain greater project impact. Participants should be faculty members and occupy mid-level administrative positions in their respective organizations. This is to ensure a better decision making influence in incorporating the subject matter into agroforestry education during any curriculum development and review processes. There is also a need for proactive follow-up on the implementation of the individual action plans formulated by training participants to avail themselves of the SEANAFE small grants for project output mainstreaming.

8. The presence of a curriculum framework and Teacher's Guide makes the integration of multidisciplinary subject matter into existing agroforestry and related courses much easier. Such material can provide good ideas to universities on how and where improvements can be made to existing course curricula. 


\section{Some Challenges in Institutionalizing SEANAFE Project Experiences and Outputs}

SEANAFE sees the following major challenges to the future institutionalization of its project experiences and outputs to facilitate the building of capacity for region-wide curriculum and teaching materials development in agroforestry education in the SEA region:

- Institutional support and full recognition of the project approaches by SEANAFE member institutions to ensure the adoption of project outputs, considering the variation in the way course curricula are developed in the different member countries

- Differences among SEANAFE member institutions in the content and mode of offering of agroforestry courses and programs

- The relatively high cost requirement to generate the expected outputs and outcomes

- Familiarity and readiness of lecturers from SEANAFE member institutions to adopt the case study approach in their teaching

- Availability of other case study and reference material in SEANAFE countries that would enable lecturers to teach the curriculum framework themes adequately 


\section{References}

SEANAFE. 2005. "Sharing Knowledge on Markets, Landscapes and Environmental Policies" Project Phase 2. World Agroforestry Centre-Southeast Asia Regional Office. Bogor, Indonesia.

SEANAFE. 2005. "Markets for Agroforestry Tree Products: Project Overview." World Agroforestry Centre-Southeast Asia Regional Office, Bogor, Indonesia.

SEANAFE. 2006. "Landscape Agroforestry: Project Overview." World Agroforestry CentreSoutheast Asia Regional Office, Bogor, Indonesia.

http://webinstituteforteachers.org/curriculumTerms/extra.htm

Yin, R. K. 1984. Case Study Research: Design and Methods. Newbury Park, CA: Sage Publications.

Stake, R. E. 1995. The Art of Case Study Research. Thousand Oaks, CA: Sage Publications.

Librando, P. (undated). "The Case Study: From Conceptualization to Write-Up.” A Handout from International Institute of Rural Reconstruction. Cavite, Philippines. 


\section{Attachment 1}

Regional Training and Planning Workshop on Markets for Agroforestry Tree Products 21-26 November 2005, RECOFTC, Bangkok, Thailand

Monday, 21 November

\begin{tabular}{|c|c|c|}
\hline Time & Activity & In-Charge \\
\hline 08:30-09:00 & Registration & SEANAFE Secretariat \\
\hline 09:00-10:00 & $\begin{array}{l}\text { Opening Session } \\
\text { - Welcome Address } \\
\text { - Keynote Speech } \\
\text { Overview on Training-Workshop Objectives and } \\
\text { Program }\end{array}$ & $\begin{array}{l}\text { Dr. Monton Jamroenprucksa, } \\
\text { SEANAFE Board Chair } \\
\text { Dr. Yam Malla, RECOFTC } \\
\text { Director General } \\
\text { Prof. Dr. Songkram } \\
\text { Thammincha, former KU } \\
\text { President } \\
\text { Mr. Per Rudebjer, SEANAFE } \\
\text { Technical Adviser }\end{array}$ \\
\hline 10:00-10:30 & Coffee Break & \\
\hline \multicolumn{3}{|c|}{ Theme 1: Framing the Issues } \\
\hline $10: 30-12: 00$ & $\begin{array}{l}\text { Introduction of Participants } \\
\text { Marketing basics as applied to agroforestry tree products: } \\
\text { - Banana markets in West Java } \\
\text { - Market Information Systems }\end{array}$ & $\begin{array}{l}\text { Per Rudebjer } \\
\text { Joel Tukan, ICRAF-Bogor } \\
\text { Joost Foppes, SNV Laos }\end{array}$ \\
\hline $12: 00-13: 00$ & Lunch & \\
\hline 13:00-15:00 & $\begin{array}{l}\text { Exercise: } \\
\text { Knowledge mapping of participants' profile and } \\
\text { experiences regarding markets for agroforestry tree } \\
\text { products }\end{array}$ & Joost Foppes \\
\hline $15: 00-15: 15$ & Coffee break & \\
\hline $15: 15-16: 00$ & Standards and Certification & Matthew Markopoulos \\
\hline $16: 00-16: 30$ & Introduction to Field Day & $\begin{array}{l}\text { Somjai Srimongkontip, } \\
\text { RECOFTC } \\
\text { Per Rudebjer }\end{array}$ \\
\hline Evening & Welcome Dinner & \\
\hline
\end{tabular}

Tueday, 22 November

\begin{tabular}{|c|c|c|}
\hline Time & Activity & In-Charge \\
\hline \multicolumn{3}{|c|}{ Theme 2: Exploring the retail and wholesale of AFTPs in Bangkok: Field Day } \\
\hline 07:30-17:00 & $\begin{array}{l}\text { Field Work in } 4 \text { Groups by Themes } \\
\begin{array}{l}\text { 1. Marketing of medicinal plants and products } \\
\text { 2. Marketing of agricultural products (Thai fruits, } \\
\text { etc) } \\
\text { 3. Marketing of wooden furniture } \\
\text { 4. Marketing of rattan handicrafts }\end{array}\end{array}$ & $\begin{array}{l}\text { Somjai Srinmongkontip } \\
\text { Poom Pinthep, RECOFTC }\end{array}$ \\
\hline
\end{tabular}


Wednesday, 23 November

\begin{tabular}{|c|c|c|}
\hline Time & Activity & In-Charge \\
\hline 08:00-08:30 & $\begin{array}{l}\text { Introduction to Participatory Curriculum Development } \\
\text { (PCD) }\end{array}$ & Per Rudebjer \\
\hline 08:30-09:30 & $\begin{array}{l}\text { Group Work: Reflecting on field trip experiences and } \\
\text { preparing presentations }\end{array}$ & Joost Foppes \\
\hline 09:30-10:00 & Coffee Break & \\
\hline 10:00-11:00 & Presentation of field work experiences & Participants \\
\hline \multicolumn{3}{|c|}{ Theme 3: Understanding markets and planning to enter them } \\
\hline $11: 00-12: 00$ & Marketing: Basic Theory & $\begin{array}{l}\text { Tiago Wandschneider, } \\
\text { SADU Project, CIAT }\end{array}$ \\
\hline 12:00-13:00 & Lunch & \\
\hline 13:00-15:00 & $\begin{array}{l}\text { Enterprise Development } \\
\text { - } \quad \text { Market survey } \\
\text { - } \quad \text { Market chains } \\
\text { - } \quad \text { Importance of institutions } \\
\text { The small-scale enterprise development process (SADU): } \\
\text { Examples from Laos and Vietnam }\end{array}$ & $\begin{array}{l}\text { Willie Bourne, } \\
\text { SADU Project, CIAT }\end{array}$ \\
\hline $15: 00-15: 15$ & Coffee Break & \\
\hline $15: 15-17: 00$ & $\begin{array}{l}\text { Exercise: Mapping the knowledge, skills, and attitudes a } \\
\text { learner would need to understand markets and plan how } \\
\text { to enter them }\end{array}$ & Per Rudebjer \\
\hline
\end{tabular}

\section{Thursday, 24 November}

\begin{tabular}{|c|c|c|}
\hline Time & Activity & In-Charge \\
\hline \multicolumn{3}{|c|}{ Theme 4: Creating and managing small-scale business: gainful participation in markets } \\
\hline 08:00-12:00 & $\begin{array}{l}\text { Case Study Presentations and Discussions } \\
\text { - Mao Tree: enterprise development of wild berries } \\
\text { in Thailand } \\
\text { - The market chain/value adding: small holder } \\
\text { timber in Laos }\end{array}$ & $\begin{array}{l}\text { Somjai Srimongkontip } \\
\text { Bernard Mohns, GTZ }\end{array}$ \\
\hline 10:00-10:15 & Coffee Break & \\
\hline $10: 15-12: 00$ & $\begin{array}{l}\text { Continuation of Case Study Presentations and } \\
\text { Discussions } \\
\text { - Non Timber Forest Product Markets } \\
\text { - Bamboo and rattan markets in China }\end{array}$ & $\begin{array}{l}\text { Joost Foppes } \\
\text { Xie Chen, China's Forst } \\
\text { Economics and Development } \\
\text { Research Center }\end{array}$ \\
\hline 12:00-13:00 & Lunch & \\
\hline 13:00-17:00 & $\begin{array}{l}\text { Planning national case studies: } \\
\text { Reviewing the options and getting the first round of } \\
\text { reactions, reflections, and feedback }\end{array}$ & Country Teams \\
\hline $15: 00-15: 15$ & Coffee Break & \\
\hline $15: 15-16: 30$ & Short presentations by each national team & Country Teams \\
\hline
\end{tabular}


Friday, 25 November

\begin{tabular}{|l|l|l|}
\hline Time & \multicolumn{1}{l|}{ Activity } & \multicolumn{1}{l|}{ In-Charge } \\
\hline \multicolumn{1}{|l|}{ Theme 5: Managing the challenges of modern consumer markets: living with change } \\
\hline 08:00-09:00 & China's role in markets for agroforestry products & Xie Chen \\
\hline 09:00-10:00 & Organic \& certified production & $\begin{array}{l}\text { Wanlp Pichponsa, } \\
\text { Capital Rice }\end{array}$ \\
\hline 10:00-10-30 & Coffee Break & \\
\hline 10:30-12:00 & $\begin{array}{l}\text { Group Work 2: Regional trade: Reflections on } \\
\text { Participants' Experiences from each country }\end{array}$ & Joel Tukan \\
\hline 12:00-13:00 & Lunch & \\
\hline 13:00-15:00 & Group work presentations & Participants \\
\hline 15:00-15:15 & Coffee Break & \\
\hline 15:15-16:00 & Group work wrap up & \\
\hline
\end{tabular}

Saturday, 26 November

\begin{tabular}{|l|l|l|}
\hline Time & Activity & \multicolumn{1}{l|}{ In-Charge } \\
\hline Theme 6: Towards teaching and learning markets for ATFPs & Country Teams \\
\hline 08:30-09:30 & $\begin{array}{l}\text { Planning national case studies: } \\
\text { Agreeing on structure of project description, time plan, } \\
\text { monitoring and reporting }\end{array}$ & \\
\hline 09:30-10:00 & Coffee Break & Country Teams \\
\hline 10:00-12:00 & Continuation of Planning national case studies & \\
\hline 12:00-13:00 & Lunch & Country Teams \\
\hline 13:00-13:30 & $\begin{array}{l}\text { Brief presentation of country case study concept } \\
\text { proposals (problem, hypothesis/assumptions, objectives) } \\
\text { for peer review }\end{array}$ & \\
\hline 13:30-15:00 & Development of full country case study concept proposal & Country Teams \\
\hline 15:00-15:30 & Coffee Break & Per Rudebjer \\
\hline 15:30-16:00 & $\begin{array}{l}\text { Training-Workshop evaluation } \\
\text { Closing program }\end{array}$ & \\
\hline Evening & Closing dinner & \\
\hline
\end{tabular}




\section{Attachment 2}

\section{Regional Training cum Planning Workshop on Agroforestry Landscape Analysis}

22-26 March 2007, Rincome Hotel, Chiangmai, Thailand

\section{Thursday, 22 March}

\begin{tabular}{|c|c|c|}
\hline Time & Activity & In-charge \\
\hline 0900 & $\begin{array}{cl}\text { Opening Program } \\
\text { - } & \text { Welcome and Opening Remarks } \\
\text { - } & \text { Overview of Training-Workshop } \\
\text { - Introduction of Participants and Training- } \\
\text { - } \quad \text { Gorkshop Team } \\
\text { Group Photo }\end{array}$ & $\begin{array}{l}\text { David Thomas, ICRAF- } \\
\text { Thailand Coordinator } \\
\text { Jess C. Fernandez, } \\
\text { SEANAFE Technical Adviser }\end{array}$ \\
\hline 1015 & Coffee Break & \\
\hline 1030 & $\begin{array}{l}\text { - Surfacing of Expectations/ Mind Mapping on } \\
\text { Landscape Agroforestry } \\
\text { - Administrative Briefing }\end{array}$ & $\begin{array}{l}\text { Jess C. Fernandez } \\
\text { Pong Pramualpis, ICRAF- } \\
\text { Thailand }\end{array}$ \\
\hline 1200 & Lunch Break & \\
\hline 1330 & $\begin{array}{l}\text { Overview of Landscape Agroforestry in Southeast Asia } \\
\text { (Part 1) : Current Principles \& Perspectives }\end{array}$ & $\begin{array}{l}\text { Meine van Noordwijk, ICRAF- } \\
\text { SEA Regional Coordinator }\end{array}$ \\
\hline 1500 & Coffee Break & \\
\hline 1530 & $\begin{array}{l}\text { Overview of Landscape Agroforestry in Southeast Asia } \\
\text { (Part 2): Current Policies and Institutional Arrangements }\end{array}$ & Meine van Noordwijk \\
\hline 1700 & Integration of Learning and Evaluation & Jess C. Fernandez \\
\hline 1830 & Welcome Dinner (Kantoke) & \\
\hline
\end{tabular}

Friday, 23 March

\begin{tabular}{|c|c|c|}
\hline Time & Activity & In-charge \\
\hline 0815 & Recap of Previous Day's Insights & Host Team \\
\hline 0845 & $\begin{array}{l}\text { Defining and Valuing Landscape Agroforestry Tradeoffs: } \\
\text { Economic, Social, and Ecological Benefits and } \\
\text { Consequences }\end{array}$ & Meine van Noordwijk \\
\hline 1015 & Coffee Break & \\
\hline 1030 & $\begin{array}{l}\text { Overview of Landscape Agroforestry Research: } \\
\text { Considerations and Challenges }\end{array}$ & Meine van Noordwijk \\
\hline 1200 & Lunch Break & \\
\hline 1330 & $\begin{array}{l}\text { Analyzing and Monitoring Landscape pattern-process } \\
\text { interactions and changes: Concepts, Drivers, Knowledge } \\
\text { Sources and Methodological Considerations }\end{array}$ & $\begin{array}{l}\text { Minh Ha Fragerstrom, ICRAF- } \\
\text { Vietnam Coordinator }\end{array}$ \\
\hline 1500 & Coffee Break & \\
\hline 1530 & $\begin{array}{l}\text { Presentation of Selected Landscape Agroforestry Case } \\
\text { Studies } \\
\text { Case 1: Participatory Mapping in Thailand } \\
\text { Case 2: Watershed management in Vietnam }\end{array}$ & $\begin{array}{l}\text { Pornwilai Saipothong, ICRAF- } \\
\text { Thailand } \\
\text { Minh Ha Fragerstrom }\end{array}$ \\
\hline 1700 & Integration of Learning and Evaluation & Jess C. Fernandez \\
\hline
\end{tabular}




\section{Saturday, 24 March}

\begin{tabular}{|l|l|l|}
\hline \multicolumn{1}{|c|}{ Time } & \multicolumn{1}{c|}{ Activity } & \multicolumn{1}{c|}{ In-charge } \\
\hline 0815 & Recap of Previous Day's Insights & Host Team \\
\hline 0845 & $\begin{array}{c}\text { Framing the Landscape Agroforestry Curriculum } \\
\text { Identifying the expected competencies in AFLA } \\
\text { of would-be graduates (knowledge, skills and } \\
\text { attitudes) }\end{array}$ & $\begin{array}{l}\text { Jess C. Fernandez \& } \\
\text { Participants }\end{array}$ \\
\hline 1015 & $\begin{array}{l}\text { Coffee Break } \\
\text { Identifying AFLA key themes to address the } \\
\text { required competencies }\end{array}$ & $\begin{array}{l}\text { Jess C. Fernandez \& } \\
\text { Participants }\end{array}$ \\
\hline 1030 & Lunch Break & Jess C. Fernandez \\
\hline 1330 & $\begin{array}{l}\text { Brief orientation on conducting a case study and Planning } \\
\text { the Country AFLA case studies }\end{array}$ & Participants \\
\hline 1500 & Coffee Break & $\begin{array}{l}\text { Identifying Country Research Focus and Drafting of } \\
\text { County AFLA Case Study Concept Papers }\end{array}$ \\
\hline 1530 &
\end{tabular}

Sunday, 25 March

\begin{tabular}{|c|l|l|}
\hline Time & \multicolumn{1}{|c|}{ Activity } & \multicolumn{1}{c|}{ In-Charge } \\
\hline $0730-1500$ & Field Trip to Mae Cham & ICRAF-Thailand Staff \\
\hline $1500-1800$ & Cultural Tour of Chiang Mai City & ICRAF-Thailand Staff \\
\hline
\end{tabular}

Monday, 26 March

\begin{tabular}{|l|l|l|}
\hline \multicolumn{1}{|c|}{ Time } & \multicolumn{1}{|c|}{ Activity } & \multicolumn{1}{|c|}{ In-Charge } \\
\hline 0830 & Discussion and Synthesis of Field Trip Insights & Host Team \\
\hline 0915 & $\begin{array}{l}\text { Presentation and Discussion of Country AFLA Case Study } \\
\text { Concept Proposals }\end{array}$ & Country Coordinators \\
\hline 1015 & Coffee Break & \\
\hline 1030 & $\begin{array}{l}\text { Charting the Way Forward for Conducting Country Case } \\
\text { Studies and Discussion of Country Team Terms of } \\
\text { Reference }\end{array}$ & Jess C. Fernandez \\
\hline 1200 & $\begin{array}{l}\text { Lunch Break } \\
\text { Evaluation }\end{array}$ & Jess C. Fernandez \\
\hline 1330 & \begin{tabular}{l} 
Coffee Break \\
\hline 1530
\end{tabular} & FREE TIME \\
\hline 1800 & Closing Program and Farewell dinner & \\
\hline
\end{tabular}




\section{WORKING PAPERS IN THIS SERIES}

2005

1. Agroforestry in the drylands of eastern Africa: a call to action

2. Biodiversity conservation through agroforestry: managing tree species diversity within a network of community-based, nongovernmental, governmental and research organizations in western Kenya.

3. Invasion of prosopis juliflora and local livelihoods: Case study from the Lake Baringo area of Kenya

4. Leadership for change in farmers organizations: Training report: Ridar Hotel, Kampala, 29th March to 2nd April 2005.

5. Domestication des espèces agroforestières au Sahel : situation actuelle et perspectives

6. Relevé des données de biodiversité ligneuse: Manuel du projet biodiversité des parcs agroforestiers au Sahel

7. Improved land management in the Lake Victoria Basin: TransVic Project's draft report.

8. Livelihood capital, strategies and outcomes in the Taita hills of Kenya

9. Les espèces ligneuses et leurs usages: Les préférences des paysans dans le Cercle de Ségou, au Mali

10. La biodiversité des espèces ligneuses: Diversité arborée et unités de gestion du terroir dans le Cercle de Ségou, au Mali

11. Bird diversity and land use on the slopes of Mt. Kilimanjaro and the adjacent plains, Tanzania

12. Water, women and local social organization in the Western Kenya Highlands

13. Highlights of ongoing research of the World Agroforestry Centre in Indonesia

14. Prospects of adoption of tree-based systems in a rural landscape and its likely impacts on carbon stocks and farmers' welfare: The FALLOW Model Application in Muara Sungkai, Lampung, Sumatra, in a 'Clean Development Mechanism' context

15. Equipping integrated natural resource managers for healthy agroforestry landscapes.

16. Are they competing or compensating on farm? Status of indigenous and exotic tree species in a wide range of agro-ecological zones of Eastern and Central Kenya, surrounding Mt. Kenya.

17. Agro-biodiversity and CGIAR tree and forest science: approaches and examples from Sumatra.

18. Improving land management in eastern and southern Africa: A review of polices.

19. Farm and household economic study of Kecamatan Nanggung, Kabupaten Bogor, Indonesia: A socio-economic base line study of agroforestry innovations and livelihood enhancement.

20. Lessons from eastern Africa's unsustainable charcoal business.

21. Evolution of RELMA's approaches to land management: Lessons from two decades of research and development in eastern and southern Africa

22. Participatory watershed management: Lessons from RELMA's work with farmers in eastern Africa.

23. Strengthening farmers' organizations: The experience of RELMA and ULAMP. 
24. Promoting rainwater harvesting in eastern and southern Africa.

25. The role of livestock in integrated land management.

26. Status of carbon sequestration projects in Africa: Potential benefits and challenges to scaling up.

27. Social and Environmental Trade-Offs in Tree Species Selection: A Methodology for Identifying Niche Incompatibilities in Agroforestry

28. Managing tradeoffs in agroforestry: From conflict to collaboration in natural resource management. [Appears as AHI Working Paper no. 10]

29. Essai d'analyse de la prise en compte des systemes agroforestiers pa les legislations forestieres au Sahel: Cas du Burkina Faso, du Mali, du Niger et du Senegal.

30. Etat de la recherche agroforestière au Rwanda etude bibliographique, période 19872003

31. Science and technological innovations for improving soil fertility and management in Africa: A report for NEPAD's Science and Technology Forum.

32. Compensation and rewards for environmental services.

33. Latin American regional workshop report compensation.

34 Asia regional workshop on compensation ecosystem services.

35 Report of African regional workshop on compensation ecosystem services.

36 Exploring the inter-linkages among and between compensation and rewards for ecosystem services CRES and human well-being

37 Criteria and indicators for environmental service compensation and reward mechanisms: realistic, voluntary, conditional and pro-poor

38 The conditions for effective mechanisms of compensation and rewards for environmental services.

39 Organization and governance for fostering Pro-Poor Compensation for Environmental Services.

40 How important are different types of compensation and reward mechanisms shaping poverty and ecosystem services across Africa, Asia \& Latin America over the Next two decades?

41. Risk mitigation in contract farming: The case of poultry, cotton, woodfuel and cereals in East Africa.

42. The RELMA savings and credit experiences: Sowing the seed of sustainability

43. Yatich J., Policy and institutional context for NRM in Kenya: Challenges and opportunities for Landcare.

44. Nina-Nina Adoung Nasional di So! Field test of rapid land tenure assessment (RATA) in the Batang Toru Watershed, North Sumatera.

45. Is Hutan Tanaman Rakyat a new paradigm in community based tree planting in Indonesia?

46. Socio-Economic aspects of brackish water aquaculture (Tambak) production in Nanggroe Aceh Darrusalam.

47. Farmer livelihoods in the humid forest and moist savannah zones of Cameroon.

48. Domestication, genre et vulnérabilité : Participation des femmes, des Jeunes et des catégories les plus pauvres à la domestication des arbres agroforestiers au Cameroun.

49. Land tenure and management in the districts around Mt Elgon: An assessment presented to the Mt Elgon ecosystem conservation programme. 
50. The production and marketing of leaf meal from fodder shrubs in Tanga, Tanzania: A pro-poor enterprise for improving livestock productivity.

51. Buyers Perspective on Environmental Services (ES) and Commoditization as an approach to liberate ES markets in the Philippines.

52. Towards Towards community-driven conservation in southwest China: Reconciling state and local perceptions.

53. Biofuels in China: An Analysis of the Opportunities and Challenges of Jatropha curcas in Southwest China.

54. Jatropha curcas biodiesel production in Kenya: Economics and potential value chain development for smallholder farmers

55. Livelihoods and Forest Resources in Aceh and Nias for a Sustainable Forest Resource Management and Economic Progress.

56. Agroforestry on the interface of Orangutan Conservation and Sustainable Livelihoods in Batang Toru, North Sumatra.

\section{8}

57. Assessing Hydrological Situation of Kapuas Hulu Basin, Kapuas Hulu Regency, West Kalimantan.

58. Assessing the Hydrological Situation of Talau Watershed, Belu Regency, East Nusa Tenggara.

59. Kajian Kondisi Hidrologis DAS Talau, Kabupaten Belu, Nusa Tenggara Timur.

60. Kajian Kondisi Hidrologis DAS Kapuas Hulu, Kabupaten Kapuas Hulu, Kalimantan Barat.

61. Lessons learned from community capacity building activities to support agroforest as sustainable economic alternatives in Batang Toru orang utan habitat conservation program (Martini, Endri et al.)

62. Mainstreaming Climate Change in the Philippines.

63. A Conjoint Analysis of Farmer Preferences for Community Forestry Contracts in the Sumber Jaya Watershed, Indonesia.

64. The Highlands: A shower water tower in a changing climate and changing Asia.

65. Eco-Certification: Can It Deliver Conservation and Development in the Tropics?

66. Designing ecological and biodiversity sampling strategies. Towards mainstreaming climate change in grassland management.

67. Participatory Poverty and Livelihood Assessment Report, Kalahan, Nueva Vizcaya, the Philippines

68. An Assessment of the Potential for Carbon Finance in Rangelands

69. ECA Trade-offs Among Ecosystem Services in the Lake Victoria Basin.

70. Le business plan d'une petite entreprise rurale de production et de commercialisation des plants des arbres locaux. Cas de quatre pépinières rurales au Cameroun.

71. Les unités de transformation des produits forestiers non ligneux alimentaires au Cameroun. Diagnostic technique et stratégie de développement Honoré Tabuna et Ingratia Kayitavu.

72. Les exportateurs camerounais de safou (Dacryodes edulis) sur le marché sous régional et international. Profil, fonctionnement et stratégies de développement.

73. Impact of the Southeast Asian Network for Agroforestry Education (SEANAFE) on agroforestry education capacity.

74. Setting landscape conservation targets and promoting them through compatible land use in the Philippines. 
75. Review of methods for researching multistrata systems.

76. Study on economical viability of Jatropha curcas L. plantations in Northern Tanzania Assessing farmers' prospects via cost-benefit analysis

77. Cooperation in Agroforestry between Ministry of Forestry of Indonesia and International Center for Research in Agroforestry

78. "China's bioenergy future. an analysis through the Lens if Yunnan Province

79. Land tenure and agricultural productivity in Africa: A comparative analysis of the economics literature and recent policy strategies and reforms

80. Boundary organizations, objects and agents: linking knowledge with action in agroforestry watersheds

81. Reducing emissions from deforestation and forest degradation (REDD) in Indonesia: options and challenges for fair and efficient payment distribution mechanisms

82. Mainstreaming Climate Change into Agricultural Education: Challenges and Perspectives.

83. Challenging Conventional mindsets and disconnects in Conservation: the emerging role of eco-agriculture in Kenya's Landscape Mosaics.

84. Lesson learned RATA garut dan bengkunat: suatu upaya membedah kebijakan pelepasan kawasan hutan dan redistribusi tanah bekas kawasan hutan.

85. The emergence of forest land redistribution in Indonesia.

86. Commercial opportunities for fruit in Malawi.

87. Status of fruit production processing and marketing in Malawi.

88. Fraud in tree science.

89. Trees on farm: analysis of global extent and geographical patterns of agroforestry

90. The springs of Nyando: water, social organization and livelihoods in Western Kenya.

91. Building cpacity toward region-wide curriculum and teaching materials development in agroforestry education in Southeast Asia.

92. Overview of Biomass Energy Technology in Rural Yunnan.

93. A Pro-Growth Pathway for Reducing Net GHG Emissions in China

94. Analysis of local livelihoods from past to present in the central Kalimantan ExMega Rice Project area

95. Constraints and options to enhancing production of high quality feeds in dairy production in Kenya, Uganda and Rwanda

96. Agroforestry education in the Philippines: status report from the Southeast Asian Network for Agroforestry Education (SEANAFE)

2010

97. Economic viability of Jatropha curcas L. plantations in Northern Tanzania- assessing farmers' prospects via cost-benefit analysis.

98. Hot spot of emission and confusion: land tenure insecurity, contested policies and competing claims in the central Kalimantan Ex-Mega Rice Project area

99. Agroforestry competences and human resources needs in the Philippines.

100. CES/COS/CIS paradigms for compensation and rewards to enhance environmental Services 
The World Agroforestry Centre is an autonomous, non-profit research organization whose vision is a rural transformation in the developing world where smallholder households strategically increase their use of trees in agricultural landscapes to improve their food security, nutrition, income, health, shelter, energy resources and environmental sustainability. The Centre generates science-base knowledge about the diverse role that trees play in agricultural landscapes, and uses its research to advance policies and practices that benefit the poor and the environment.

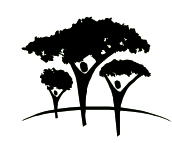

United Nations Avenue, Gigiri - PO Box 30677 - 00100 Nairobi, Kenya Tel: +254 207224000 or via USA +1 6508336645 Fax: +254207224001 or via USA +16508336646 Southeast Asia Regional Programme - Sindang Barang, Bogor 16680 PO Box161 Bogor 16001, Indonesia Tel: +62 251625415 - Fax: +62 251625416 www.worldagroforestry.org 